\title{
Sciendo
}

\section{The Common European Investment Policy and Its Perspectives in the Context of the Achmea Case Law}

\author{
Daniela Nováčková \\ Tomáš Peráček \\ Comenius University in Bratislava \\ Faculty of Management \\ Odbojárov 10 \\ Bratislava 82005, Slovakia \\ Email: daniela.novackova@fm.uniba.sk \\ Email: tomas.peracek@fm.uniba.sk
}

\begin{abstract}
Current developments in the field of international investment relations are influenced by the ruling of the Court of Justice in the Achmea case, when de facto European law became superior to international law. The verdict of the Court of Justice changes the usual legal procedures and customs in the field of bilateral investment agreements. However, the impact of this court decision is an almost unexplored area due to the lack of interest of legal theorists, and it is relatively difficult to find answers to the ambiguities and problems that have arisen. The scientific study analyses the current process of introducing new rules in the field of investment policy within the European Union, which means the end of bilateral investment agreements within the European Union. It also examines the European Union's activities in the field of foreign direct investment and the development of a stable European investment policy. Determining the goal of the scientific study is based directly on current needs and emerging practical problems in practice. Their correct understanding and application has a fundamental impact on the possibilities of rules in the field of investment policy. Due to the nature of the researched topic, we applied selected qualitative methods suitable for recognising the law. However, we also analysed scientific literature, case-law and the analogy of law, thus providing qualified answers to the application pitfalls of legal practice.
\end{abstract}


Keywords: Achmea case, Court of Justice, investments, law, treaty

\section{Introduction}

The European Union is creating the modern model of investment policy, which includes not only foreign direct investment itself, but also all operations that are associated with such investments and that are important for their implementation: payments, protection of intangible assets, e.g., intellectual property rights, etc. The common investment policy of the EU fully respects the goals pursued by the external action of the Union, including support for the rule of law, fundamental rights, and sustainable development (Ogbeide et al., 2019). The European Union and its Member States try to provide for investors with legal certainty and a stable, predictable, fair and properly regulated environment in which they could realise their investment intentions.

The current process of introducing new rules on investment policy within the European Union represents the termination of bilateral investment treaties within the European Union, even though foreign direct investment cooperation has a clear impact on the development of a stable European investment policy. The added value of cooperation between Member States, in our view, lies in the introduction of common rules in the field of investment policy. However, the milestone is the judgment of the Court of Justice in Case C-284/16 Slovak Republic v. Achmea B.V. of 6 March 2018 (hereinafter only "the Achmea case"), the significance of which opens up a debate on the impact of a court decision on the further legal development of international investment policy, as the rules on international investment protection within the European Economic Area change.

\section{Aim and methodology}

The aim of our scientific study is to provide an up-to-date, not only theoretical but also empirical, basis for clarifying the significance of the Achmea case court decision, as in our view it is a groundbreaking decision 
that has affected the system of bilateral investment agreements as well as the validity and enforceability of bilateral investment agreements concluded between the Member States of the European Union. As part of our research, we focus directly on the development of legal acts and agreements concerning investment relations policy and on the decisions in the Achmea case.

In order to achieve the goal, we have applied several scientific research methods suitable for the cognition of law. We apply the method of synthesis-intended primarily to combine partial information into a single unit in order to combine partial conclusions concerning the impact of the European Court's ruling in the Achmea case changing the long-established system of international investment law. The synthesis will allow us to make the connections between the acquired knowledge in the field of universal theory of international investment relations and the current approach of the European Union in the formation of a common investment policy. We use the deduction method to clarify the universal theory of international investment relations, pointing to the fact that some elements of international investment law are also applied in European investment agreements. The specification method will allow us to specify the arbitration clauses provided for in bilateral investment agreements within the Member States of the European Union (hereinafter referred to as "EU-intra BITs"), which are in conflict with its agreements. Using the abstraction method, we define general and essential information concerning the termination of bilateral investment agreements concluded by the Member States of the European Union.

\section{Literature review}

The most visible manifestation of the development of Member States' investment cooperation is that they have recently concluded a large number of bilateral investment treaties, not only EU-intra BITs but also BITs with third countries. The inflow of foreign direct investment into the territory of the EU Member States, which is both the cause and consequence of globalisation, represents the reflection of pro-European investment policy.

Kurek is of the opinion that

the agreements on protection and promotion of investments are considered as an effective way to promote and protect investments from 
investors in the territory of the host state. The universal principle of these agreements is that the investment is usually provided with the protection on the basis of the principle of national treatment or most favoured nation principle, while the treatment with investment itself depends on the internal legal regulation of each state. In other words, foreign investment cannot be treated worse in the host country than domestic investment. The "minimum standard of investment protection" is the standard of "impartial and fair treatment" in most BITs. (Kurek, 2016)

According to Haller,

foreign investment treaties are based on the presumption that the guarantees provided to foreign investors by the domestic legal system of the host country may be-or may turn out to be-insufficient for the special purpose intended by those treaties, which is primarily the creation of an investment friendly climate designed to attract the foreign investment desired by the host state. (Haller, 2020, pp. 150-170)

Bigelow-Nuttall claims that

BITs are international agreements signed between two states which establish the terms and conditions for private investment by nationals and companies of one state in the other state. They usually incorporate alternative dispute resolution mechanisms. For example, a BIT may provide that any disputes be referred to arbitration under the auspices of an international arbitration institution such as the International Centre for the Settlement of Investment Disputes (ICSID), rather than allowing the state to be sued in its own courts. (Bigelow-Nuttall, 2019)

\section{Development of relations in the field of protection and promotion of investments in the Slovak Republic}

The conclusion of international agreements in the field of investment protection and promotion has its history. According to scientific literature "together with agreements on avoidance of double taxation they create the suitable instrument of international law aimed at regulation of legal relations in the field of development of investments, commerce and services" (Androniceanu, 2020, pp. 137-149). The development of international investment relations thus does not only have an economic, but also a legal 
dimension, because those international agreements stipulate the conditions for the protection of the investor's investment in the territory of another state and the conditions for the support and development of investment relations. These agreements are designed as bilateral investment agreements (BITs) in the practice and theory of economy.

According to Dolzer and Schreuer,

the first significant document on the protection of investment at the international level was the proposal of the Organisation for Economic Cooperation and Development named Magna Charta for Protection of Foreign Property (1957), which provided for the standards of protection of investments as well as the rules of investment arbitration. (Dolzer \& Schreuer, 2012, pp. 69-71)

The draft Charter could at that time be described as the global instrument of regulation and development of investment relations among the states.

The protection of investments within the framework of the European Union ranks among the areas of priority interest, however, their regulation has been left to the Member States. A certain turning point came when the states of Central and Eastern Europe started to prepare for the full-fledged membership in the European Union. As part of the process of preparing the Slovak Republic for its full membership in the European Union, the Slovak Republic was bound to harmonise valid international agreements with the legislation of the European Communities (today the European Union). International agreements usually represent the main source of legal regulation, not only bilateral but also multilateral, among the states. They provide the legal basis for multilateral international cooperation. According to Funta,

the condition of harmonisation of international treaties with the acquis communautaire formed part of the Negotiation Chapter No. 26 External Relations, of the Accession Agreement to the EU (2003), of Article 6, paragraph 10 of the Accession Act, as well as of Article 307 of the Treaty Establishing the European Community (today the Treaty on the Functioning of the European Union). (Funta, 2012, pp. 35-47)

Within the process of preparation of the Slovak Republic to its membership in the European Union, the European Commission identified the Treaty between the Czech and Slovak Federal Republic and the United States on Reciprocal Encouragement and Protection of Investment (came into force on 
19 December 1992 on the basis of its Article XIV) as an agreement that is not in conformity with the acquis communautaire (Dicu et al., 2019, pp. 510-530). This agreement was in conflict with the following articles of the Treaty of the European Community: Article 57, paragraph 2, Articles 59, 60, 119 and 120. This agreement was subsequently renegotiated by its Contracting Parties in accordance with the recommendations of the European Commission.

To further the negotiations with the European Commission the Memorandum of Understanding related to bilateral investment treaty with the United States and the Protocols related to the interpretation of bilateral investment treaties were signed with the United States on 2 September 2003. The discrepancy between the provisions of BIT with the acquis communautaire was removed by the Additional Protocol concluded between the Slovak Republic and the United States of America to the Treaty between the Czech and Slovak Federal Republic and the United States on reciprocal encouragement and protection of investments.

Based on this connection, we can point out the case-law of the Court of Justice related to the incompatibility of bilateral investment agreements with the $\mathrm{EC} / \mathrm{EU}$ law, as the Slovak Republic was not the only state having concluded a valid international agreement on the protection and encouragement of investments, which was in contradiction with the acquis communautaire. The Court of Justice in several cases C-205/06 in Judgement of 3 March 2009 decided on the compatibility of BITs with the EU law and repeatedly declared having taken appropriate steps to eliminate incompatibilities concerning the provisions on transfer of capital contained in the investment agreements.

According to Mendez-Pinedo, these facts point to that

the area of bilateral investment treaties was never an easy one and that the legal development in the field of protection and promotion of investments in Slovakia brings fundamental changes, in particular from the view of international contractual law as well as European law. (Mendez-Pinedo, 2020, pp. 390-418)

It can be clearly stated that together with the membership of the Slovak Republic in the European Union, the system of concluding bilateral investment agreements has been changed, and especially that the Slovak Republic was obliged to ensure a uniform application and implementation of the Union law on the basis of the principle of sincere cooperation enshrined in Article 4(3) of the TEU. Moreover, it has to take all measures of general 
and particular nature, in order to ensure the fulfilment of obligations arising out of the Treaties or resulting from the acts of the institutions of the EU.

\section{Regime of the European Union in the field of development of investment relations}

The Regulation (EU) No. 1219/2012 of the European Parliament and of the Council from the 12 December of 2012 establishing transitional arrangements for bilateral investment agreements between Member States and third countries addresses the status of the bilateral investment agreements of the Member States under Union law, and establishes the terms, conditions and procedures under which the Member States are authorised to amend or conclude bilateral investment agreements. The Member States are required to take the necessary measures to eliminate incompatibilities where they exist, with Union law, contained in bilateral investment agreements concluded between them and third countries. The Slovak Republic complies with the opinion of the European Commission on the compatibility of BITs with the EU law.

Following the decision of the Achmea case at the EU level the Declaration of the Member States of 15 January 2019 on the legal consequences of the Achmea judgment and on investment protection was adopted (European Commission, 2019). In the political Declaration, the Member States committed in particular to terminate all bilateral investment treaties concluded between two EU Member States (intra-EU BITs). The Slovak Republic supports a comprehensive agreement to effectively implement the Achmea judgement in line with the content of the Declaration and for the purpose of enhancing legal certainty. In addition, in order to push forward implementation of the judgement, the Slovak Republic, in parallel with the negotiations of the multilateral Agreement, initiated necessary steps for the bilateral termination of its intra-EU BITs (Ministry of Finance of the Slovak Republic, 2019). 


\section{Consequences of the Achmea decision to the international investment policy}

The judgement in the Achmea case has its impacts on the bilateral investment agreements concluded among Member States of the European Union. According to the Court of Justice EU, the Agreement on encouragement and reciprocal protection of investments between the Kingdom of the Netherlands and the Czech and Slovak Federative Republic introduced the dispute settlement mechanism, which cannot ensure that this dispute would be treated by the court belonging to the judicial system of the European Union, since it is the only court that can ensure the full effectiveness of the European Union law. According to the position of the Slovak Republic, the arbitration clause that introduced BIT is not in accordance with the provision of Articles 18, 267 and 344 of the Treaty on the Functioning of the European Union.

The Court of Justice of the European Union has clearly reached the opinion that the arbitration clause concluded according to the BIT endangers the autonomy of the European Union law, and therefore it is not compatible with the European Union law. In other words, the sued Member State would be in a position to claim the lack of competence of the arbitration court and to have the case decided following the incompatibility of arbitration award contained in BIT with the European Union law. This decision thus changes the tendencies within the international investment arbitrations. According to Noskova,

it would not be ethical if we would not point out the opinion of the advocate general of the Court of Justice Wathelet who points out clearly that so called intra EU BITs, including the BIT applicable between the Netherlands and Slovakia are in accordance with the EU law and that does not constitute discrimination on the ground of nationality, prohibited by Article 18 TFEU. (Noskova, 2019, pp. 11-12)

However, the Court of Justice of the EU in the subject matter holds a different legal view and explicitly declared the arbitration clause contained in Agreement on encouragement and reciprocal protection of investments between the Kingdom of the Netherlands and the Czech and Slovak Federative Republic, according to which all disputes involving investors from the Contracting Parties settled through arbitration proceedings according to UNCITRAL rules as incompatible with the Union law. 
The EU law is based on the fundamental premise that each Member State shares with all the other Member States it recognises that they share with it a set of common values on which the EU is founded, as stated in Article 2 of the TEU. This premise implies and justifies the existence of mutual trust between the Member States that those values will be recognised, and therefore that the law of the EU that implements them will be respected. In this connection Funta also points out the decision of the Court of Justice of the European Communities in case C-26/62, where it held that

the European Economic Community constitutes a new legal order of international law for the benefit of which the states have limited their sovereign rights, albeit within limited fields, and the subjects of which comprise not only the member states but also their nationals" (Funta, 2018, pp. 214-223)

It is worth mentioning that during the process of accession of the Slovak Republic to its membership in the European Union the said agreement was not a subject of negotiations as regards its incompatibility with acquis communautaire (today EU law). That is why we have also devoted considerable attention in the previous part of the scientific study to the problematics of harmonisation of valid international treaties with the acquis communautauire. In a given context, we clearly hold the view that the obligation to terminate the validity of bilateral investment treaties (intra) resulted from the decision of the Achmea case. Further to Article 4, paragraph 3 of the Treaty on the Functioning of the European Union, the Member States are obliged to act in accordance with this decision.

We are of the opinion that the decision in the Achmea case has a major impact on the bilateral investment agreements that govern the development of investment relations between the Member States of the European Union. However, even according to some experts (e.g., Dan, 2014, pp. 68-84), the question of which legal instruments will regulate foreign direct investment of third countries is appropriate. According to Kosach et al. (2020, pp. 139152 ), investments from third countries are subject to the provisions on the free movement of capital contained in the Treaty on the Functioning of the European Union, including portfolio investments between the European Union and third countries. As further stated by Milos and Milos (2019, pp. 113-125), the liberalisation of capital movements outside the European Union cannot be effective unless third countries remove their own restrictions on the movement of capital between the European Union and their territory. However, this usually requires the conclusion of international agreements 
with these countries based on reciprocity. However, Popa (2020, pp. 455-465) and Prokopenko et al. (2019, pp. 380-394) refer in this connection to Article 63 of the Treaty on the Functioning of the European Union. According to them, the European Union clearly has the necessary power to regulate the movement of capital (direct investment and portfolio investment) between Member States and between Member States and third countries in the context of liberalisation. However, we are also concerned about possible discrimination against investors from third countries (Androniceanu et al., 2020, pp. 6-20). The abolition of intra-EU BITs will not solve all problems, as the Member States would also have to terminate agreements with third countries.

\section{International legal framework related to termination of intra-EU BITs}

According to Mucha, "some Member States have shown their interest in common approach in termination of bilateral investment treaties. The EU Member States have started to conclude the treaties of this type especially after 1990, it means during times where many of them were not members of the European Union." (Mucha, 2019, pp. 573-580)

Within the framework of the process of deepening the European economic integration and especially introducing the rules regulating the proper functioning of the EU single market, these agreements have ceased to have legal importance, since the problematics of freedom of establishment, free movement of capital and payments, are regulated by the EU primary law and in the secondary law. The principle of prohibition of discrimination based on nationality and fair access to trade relates to all investors from the EU Member States (Drelich-Skulska et al., 2019, pp. 783-801). The problematics is often the subject of disputes before the Court of Justice of the EU. Bilateral investment treaties contain arbitration clauses, which belong to traditional institutes of international agreements. Mura and Hajduová state "that some arbitration clauses regulated in intra-EU BITs, it means among Member States of the European Union, contradict the primary law of the EU" (Mura \& Hajduová, 2021, pp. 478-503). Because of this incompatibility with the EU law, they cannot be applied in practice. The European Commission within its competences have invited some Member States (Austria, Romania, Slovakia, Netherlands and Sweden) to terminate the valid concluded bilateral 
investment agreements or to adjust them so that they would be in line with the EU law. Some Member States, Ireland and Italy, have terminated the validity of such agreements binding between them.

As Benda-Pokeinová and others state,

all measures and initiatives taken at the level of the European Union have resulted in a mutual agreement of the Member States to conclude Agreement for the termination of bilateral investment treaties between the member states of the European Union. (Benda-Pokeinová et al., 2017, pp. 15-29)

As stated above, some Member States, mainly Sweden, Finland, Ireland and Austria (and the United Kingdom, which at the time was still an EU Member State) were not in favour of concluding such an agreement. From the perspective of international contractual law it represents the multilateral international agreement. Dan (2018, pp. 846-853) emphasises that "this agreement changes the policy of the international investment relations." The draft of Agreement agreed by the Member States was developed by an ad hoc group of Member States, coordinated by the European Commission. In a broader context, it represents the manifestation of coordinated cooperation among the Member States.

The aim of this Agreement is the termination of validity and enforceability of intra-EU BITs, as well as stipulation of the rights and obligations of investors and the EU Member States within the pending arbitration proceedings. The Annex forms a part of this Agreement containing a list of bilateral investment treaties that are terminated by this Agreement. The Agreement regulates two subjects-how the existing intra-EU BITs are to be terminated, including their sunset clause and how to deal with new, pending and concluded arbitration proceedings. After entering into force of this Agreement, it will not be possible to initiate new arbitration proceedings between investors from one Member State and another Member State of the EU. Horváthová and Čajková point out that

potential future disputes of an investor from one EU Member State and another EU Member State that will arise after the termination of BITs will be tried before national courts of other EU Member States and under its national legislation that is in line with the EU law or other out of court settlement mechanisms, which are being discussed at present at the level of the European Commission. (Horváthová \& Čajková, 2018, pp. 412-425) 
In this context, we consider it necessary to reflect on and discuss the need for a change in the situation so that bilateral investment agreements concluded between Member States remain valid and enforceable. However, according to Srebalová and others,

a key question arises. The Slovak Republic has been a part of international contractual relations since 1993. At the time of accession to the European Union, it had already concluded several bilateral investment agreements with several of the original Member States. (Srebalová et al., 2020, pp. 3385-3394)

When concluding these agreements as part of the negotiation process, no objections were raised as to the compatibility of the international agreement with the applicable legal order of the European Union. These agreements served as support instruments for the inflow of investments, which also supported the transformation process in Slovakia. With the entry into force of the Lisbon Treaty, there is a presumption that it has not caused the current state of need to end intra-EU BITs. If we look at the termination from the point of view of the Vienna Convention on the Law of Treaties, we are of the opinion that the provisions of Articles 59 and 65 of this Convention have not been respected. The agenda of ongoing investment disputes conducted under intra-EU BITs also remains problematic. Probably unrealistic is our idea that, from the persepctive of international contract law, it would be better if these agreements remained in force, because the status of states to be a direct participant in these relations would be preserved. However, according to Zhao et al. (2020, pp. 166-190) and Vilcekova (2016, pp. 126-129), the process of European economic integration is evolving dynamically and some policies require adjustments. And this is where there is room for deepening European integration in connection with the provision of Article 207 of the Treaty on the Functioning of the European Union. However, our vision of maintaining these agreements will not materialise. This is evidenced by the move by Italy to terminate its bilateral investment treaties within the EU, with the exception of Malta. The Slovak Republic also terminated its bilateral investment agreements within the EU with Denmark on 13 November 2020. 


\section{Conclusion}

With regard to the stipulated aim of this study, we have, using the analysis of scientific literature, international treaties, agreements and other documents with international dimension, as well as the relevant case-law of the Court of Justice and also using the institute of legal logics, reached the conclusion that the decision of the Court of Justice in the Achmea case changes the original legal state of play in the field of investment relations among the EU Member States.

The added value of our research are several findings. The current legal development in the area of the European investment policy will be more complex, not only from an economic, but also from a legal point of view. The system of international legal regulation of the protection and promotion of investments as well as the dispute settlement system is being changed, by which also the position of the International Centre for Settlement of Investment Disputes will be weakened. There will be two categories of investors: investors from the EU Member States and investors from third countries. The European investment policy introduces the new mechanism of dispute settlement among the Member States as well as the obligation of Member States to denounce valid international agreements. This approach taken by the European Union can also be described as a tool for deepening European integration.

The result of our examination is, among other things, the finding that the institution of the European Union's exclusive competence in relation to foreign direct investment is fundamentally changing the international investment regime. The Court of Justice has ruled on the interpretation of the provisions of the relevant international agreement and on the interpretation of the autonomy of the legal system of the Union. The shaping of the European Union's common investment policy deepens the process of European economic integration. However, we consider it particularly important to find that the reason for the termination of an international agreement is a decision of the Court of Justice, and not a free decision of a Member State. The case of the Slovak Republic has become an important judicial precedent, resulting in a new legal situation where it is no longer possible to explicitly claim that European Union law automatically takes precedence over other international obligations. 


\section{Acknowledgment}

This work was supported by the Faculty of Management, Comenius University in Bratislava, Slovak Republic.

Daniela Nováčková is a professor at the Department of International Management, guarantor of the study program International Management at the Comenius University in Bratislava. In her scientific activity, she focuses mainly on the study of investment law and state aid.

Tomáš Peráček is an associate professor at the Department of Information Systems at the Comenius University in Bratislava, where he teaches commercial law and securities law. In his scientific work, he focuses primarily on commercial law and securities law.

\section{References}

Androniceanu, A. (2020), 'Major structural changes in the EU policies due to the problems and risks caused by COVID-19,' Administratie si Management Public, vol. 34, pp. 137-149. https://doi.org/10.24818/amp/2020.34-08

Androniceanu, A.; Kinnunen, J. \& Georgescu, I. (2020), 'E-Government clusters in the EU based on the Gaussian Mixture Models,' Administratie si Management Public, vol. 35, pp. 6-20, https://doi.org/10.24818/amp/2020.35-01

Benda-Prokeinová, R.; Dobeš, K.; Mura, L. \& Buleca, J. (2017). ‘Engel’s approach as a tool for estimating consumer behaviour,' $E \&$ M Ekonomie a Management, vol. 20, no. 2, pp. 15-29. https://doi.org/10.15240/tul/001/2017-2-002

Bigelow-Nuttall, C. (2019), 'EU states agree treaty to terminate bilateral investment treaties,' Outlaw News, 5. November. Retrieved from https:// www.pinsentmasons.com/out-law/news/eu-states-agree-treaty-to-terminatebilateral-investment-treaties [accessed 5 Mar 2021]

Budějovický Budvar National Corporation v. Rudolf Ammersin GmbH [2009], ECR 1, C-478/07, pp. 12-13.

Ceskoslovenska obchodni banka a.s. v. Slovak Republic [2000], ICSID, ARB/97/4, p. 544 .

Commission of the European Communities v. Kingdom of Sweden [2009], ECR 1, C-205/06, p. 01303. 
Consolidated versions of the Treaty on European Union and the Treaty on the Functioning of the European Union, OJ C 326, 26.10.2012, pp. 0001-0390.

Dan, H. (2014), 'The Euro zone-between fiscal heterogeneity and monetary unity,' Transylvanian Review of Administrative Sciences, no. 43E (October), pp. 68-84.

Dan, H. (2018), 'Cultural influences on competitiveness in the European Union. An exploration of causality,' Paper presented at Transylvanian International Conference in Public Administration, Cluj-Napoca, Romania, 2-4 November 2017.

Dicu, R. M.; Toma, C.; Aevoae, G. M. \& Mardiros, D. N. (2019), 'The influence of deal value's determinants in mergers and acquisitions with community dimension: some empirical evidence from the European Union,' Transformations in Business \& Economics, vol. 18, no. 2A (47A), pp. 510-530.

Dolzer, R. \& Schreuer, Ch. (2012), Principles of International Investment Law, 2nd ed., Oxford: Oxford University Press. https://doi.org/10.1093/law/9780199651795.001.0001

Drelich-Skulska, B. \& Jankowiak, A. H. (2019), 'The meaning of cluster policy in the process of integration between the European Union Member States,' Transformations in Business \& Economics, vol. 18, no. 2B (47B), pp. 783-801.

European Commission (2019), Declaration of the Representatives of the Governments of the Member States of 15 January 2019 on the legal consequences of the Court of Justice in Achmea and on investment protection in the European Union, 17.1.2019. Retrieved from https://ec.europa.eu/info/publications/190117bilateral-investment-treaties_en [accessed 5 Mar 2021]

Funta, R. (2012), 'Legal and economic analysis of cartels, their enforcement and the leniency program,' Danube, vol. 1, no. 1, pp. 35-47.

Funta, R. (2018), 'Extraterritorial application of us-antitrust law on global cartels from comparative (EU LAW) perspective,' Lawyer Quarterly, vol. 8, no. 3, pp. 214-223.

Haller, A. (2020), 'From classical and neoclassical economic growth to degrowth in Europe. Challenges for public administration,' Administratie si Management Public, vol. 34, pp. 150-170. https://doi.org/10.24818/amp/2020.34-9

Horváthová, Z. \& Čajková, A. (2018), 'Social and economic aspects of the EU's education policy,' Integration of Education, vol. 22, no. 3, pp. 412-425. https:// doi.org/10.15507/1991-9468.092.022.201803.412-425

Kosach, I.; Duka, A.; Starchenko, G.; Myhaylovska, O. \& Zhavoronok, A. (2020), 'Socioeconomic viability of public management in the context of European integration processes,' Administratie si Management Public, vol. 35, pp. 139-152. https://doi.org/ 10.24818/amp/2020.35-09

Kurek, P. (2016), 'Investment structuring in the context of investment treaty protections,' Arbitration blog, 4 July. Retrieved from http://arbitrationblog. 
practicallaw.com/investment-structuring-in-the-context-of-investment-treatyprotections/ [accessed 5 Mar 2021]

Mendez-Pinedo, M. E. (2020), 'Constitutional/judicial resistance to European Law in Iceland. Sovereignty and constitutional identity vs. access to justice under the EEA Agreement,' Juridical Tribune (Tribuna Juridica), vol. 10, no. 3, pp. 390-418.

Milos, M. C. \& Milos, L. R. (2019), 'Investor protection and stock market development. Empirical approach on the European Union case,' Juridical Tribune (Tribuna Juridica), vol. 9, no. 1, pp. 113-125.

Ministry of Finance of the Slovak Republic (2019), Declaration on the legal consequences of the judgment of the Court of Justice in Achmea, Bratislava: VEDA.

Mucha, B. (2019), 'Tools to increase the effectiveness of comprehensive management of emergencies affected by climate change in the Slovak Republic,' Proceedings of International Multidisciplinary Scientific GeoConference Surveying Geology and Mining Ecology Management, SGEM, vol. 19, no. 5.4, pp. 573-580. https:// doi.org/10.5593/sgem2019/5.4/S23.075

Mura, L. \& Hajduová, Z. (2021), 'Measuring efficiency by using selected determinants in regional SMEs,' Entrepreneurship and Sustainability Issues, vol. 8, no. 3, pp. 487-503. https://doi.org/10.9770/jesi.2021.8.3(31)

Noskova, M. (2019), International Business Law, Bratislava: Comenius University. NV Algemene Transport - en Expeditie Onderneming van Gend \& Loos v. Netherlands Inland [1963], Revenue Administration Reference for a preliminary ruling: Tariefcommissie-Netherlands, ECR 1, C-26-62, p. 2

Ogbeide, S. O.; Ogiugo, H. U. \& Adesuyi, I. O. (2021), 'Corporate governance mechanisms and financial reporting quality of commercial banks in Nigeria,' Insights into Regional Development, vol. 3, no. 1, pp. 136-146.

https://doi.org/10.9770/IRD.2021.3.1(8)

Popa (Tache), C. E. (2020), 'International investment protection in front of the states role in crisis times to managing disputes,' Juridical Tribune (Tribuna Juridica), vol. 10, no. 3, pp. 455-465.

Prokopenko, O.; Slatvinskyi, M.; Bikoshkurska, N.; Biloshkurskyi, M. \& Omelyanenko, V. (2019), 'Methodology of national investment and innovation security analytics,' Problems and Perspectives in Management, vol. 17, no. 1, pp. 380-394. https://doi.org/10.21511/ppm.17(1).2019.33

Regulation (EU) No. 1219/2012 of the European Parliament and of the Council of 12 December 2012 establishing transitional arrangements for bilateral investment agreements between Member States and third countries, OJ L351, 20.12.2012, pp. 40-46.

Slowakische Republik v. Achmea BV [2018], ECR 1 C-284/16, pp. 7-8.

Srebalová, M.; Horvat, M.; Vačok, J.; Vojtech, F. \& Filip, S. (2020), 'Legal 
obstacles to freedom to conduct a business: experience of the Slovak Republic,' Entrepreneurship and Sustainability Issues, vol. 7, no. 4, pp. 3385-3394. https://doi.org/10.9770/jesi.2020.7.4(53)

Vilcekova, L. (2016), 'Advertising credibility across different media channels,' Paper presented at the 3rd International Conference on Education and Social Sciences (INTCESS), Istanbul, Turkey, 8-10 February.

Zhao, Y. L.; Liu, F. Y.; Liu, C. Y.; Usman, M. \& Dutta, K. D. (2020), 'Readability of annual report and inefficient investment: evidence from debt financing,' Transformations in Business \& Economics, vol. 19, no. 1(49), pp. 166-190. 